\title{
Lidija Bencetić
}

\section{Journal Istarski Borac/IBOR in the Context of the Culture of Dissent}

\section{IZVLEČEK}

\section{ČASOPIS ISTARSKI BORAC/IBOR V KONTEKSTU KULTURE DISIDENTSTVA}

Prvi hrvaški mladinski časopis Istarski borac/IBOR je z dvema krajšima vmesnima premoroma izhajal med leti 1953 in 1979 v Pulju. Časopis je izdajal Književni klub Istarski borac, in sicer $z$ namenom ohranjanja hrvaškega jezika $v$ Istri kot temeljnim vodilom. $V$ sedemdesetih letih 20. stoletja je časopis prevzel značaj kritičnega medija in postopoma uvajal vse več kulturnih, lokalnih in družbenih tem, katerih ton pa socialistična oblast ni dobro sprejela. Jeseni 1979 je izbruhnil $\gg$ primer IBOR «. Časopisu so istega leta ukinili financiranje, zaradi česar je prenehal izhajati. Povod za ukinitev časopisa je bila sicer pesem $z$ naslovom Please, master (hrv:: Molim te, učitelju) Allena Ginsberga, toda partijski dokumenti razkrivajo, da je bil razlog političen. Pričujoča razprava poskuša odgovoriti na vprašanje, ali je delovanje zadnjega uredništva časopisa Istarski borac/IBOR mogoče obravnavati kot kulturo disidentstva.

Ključne besede: Istarski borac, IBOR, kultura disidentstva, mladinski tisk, Jugoslavija

\section{ABSTRACT}

The first Croatian youth journal Istarski borac/IBOR was published in Pula from 1953 to 1979 (with two minor interruptions). The journal was published by the Istarski Borac Literary Club with the objective of preserving the Croatian language in Istria. The journal developed a reputation as a critical media in the 1970s, covering more and more cultural, local and social themes whose tone was not well - received by the socialist authorities, so the financing of the journal was cancelled in 1979 after which it ceased publication. The reason

* Research Fellow, PhD, Croatian Institute of History, Opatička 10, 10000-Zagreb, Croatia, lidija.bencetic@gmail. com 
for the suspension of the journal was the poem "Please Master" by Allen Ginsberg, but the party documents reveal that the motive was also political. The question this article is trying to answer is whether the work of the last editorial board of Istarski borac/IBOR can be considered a culture of dissent.

Keywords: Istarski borac, IBOR, culture of dissent, youth press, Yugoslavia

\section{Introduction}

The youth journal of Pula Gymnasium students, Istarski borac was launched in Pula on October 15, 1953. The first issue of Istarski borac was released at the initiative of the literary section of the Branko Semelić Gymnasium and their mentor Ljubica Ivezić, with the subtitle Literary Section Gazette of the Branko Semelić Gymnasium. As of the second issue, the journal was called the "Istrian Youth Journal" and was financed by the National Youth District Committee, and this status was likely obtained through the party line. According to Ljubica Ivezić, the editorial section was reserved for ideological and political articles. ${ }^{1}$

It was the first youth journal in Yugoslavia, which was published continually, with two interruptions (from 1964 to 1969 and from 1974 to 1976) until September 1979, i.e. until the "IBOR Case" arose. Istarski borac is important to the development of the Croatian language, literature and culture in Istria, especially in terms of the development of young writers and intellectuals who later became important to the development of culture, history and socio-political life in Istria. Ljubica Ivezić, the initiator of Istarski borac, explained it this way: the students "took on the task of using their literary and cultural work in the first place to fight for the affirmation of their domestic word, which was severely persecuted under the Italian fascism". ${ }^{2}$ In the introduction to the first issue of Istarski borac, the editorial board explained the reasons for launching the journal: "The authors of original works will find their topics firstly in their personal lives, then in Istrian and Yugoslav socialistic reality. With this kind of work, we will foster a love for the mother tongue, for our socialist country and our people. We will constantly prove to each and every one that the youngest Istrian generations do not want to substitute their beloved native tongue with a foreign one, nor their national government for dominion by foreigners ever again."3 The journal was intended for young people from elementary school to university students and mostly financed by the Self-management Interest Community (SIC, croatian: Samoupravna interesna zajednica - SIZ) for the culture of the Municipality of Pula. The funding of the journal

1 Ljubica Ivezić, “I jedna važna obljetnica između na koju ne treba zaboraviti,” Dometi (Rijeka), No. 5-6 (1992): 95-100.

2 Ibid., 97.

3 Istarski borac (Pula), No. 1 (1953): 1. 
was increased between 1973 and 1979, amounting from 20,000 dinars in 1973 to 50,000 in 1978 and 74,000 in $1979 .{ }^{4}$

However, as time passed, the circumstances, policies and generations changed and the editorial approach of Istarski borac also changed, and it no longer sided with the Party. A different attitude toward the journal was first reflected in critiques of their work presented at the Party's meetings as well as publicly, and later in the termination of their funding, which was the end of the journal. According to a member of the last editorial board, Boris Domagoj Biletić: "Istarski borac was the only truly democratic light of the written word not only by young people in Istria and beyond, sometimes formally but most often never under the control of any political institution, from the beginning of the 1950s until democratic changes in 1990".

Did Istarski borac/IBOR really oppose the dogmas imposed by the Party and the selfmanaging socialist system that it was supposed to promote in its publications? Or was it about the generational gap and conservative social environment in which the journal was being published and where there was no place for poems like "Please Master"? Maybe it was a combination of one and the other, together with non-fulfillment of obligations by the editorial board that published only a half of the planned issues for 1978 and 1979?

\section{The Youth Press in the 1970s and 1980s}

The Yugoslav authorities used the youth press as a tool of youth organizations - Socialist Youth of Croatia (SYC, Croatian: Socijalistička omladina Hrvatske $\mathrm{SOH}$ ) and later the Alliance of Socialist Youth of Croatia (ASYC, Croatian: Savez socijalističke omladine Hrvatske - $\mathrm{SSOH}$ ) to indoctrinate, educate and direct the activities of young people according to the guidelines of the League of Communists of Croatia (LCC, Croatian: Saveza komunista Hrvatske - SKH).${ }^{6}$ However, with its engagement and the introduction of numerous novelties (design, popular culture from the West, analysis of neglected social themes) the youth press established itself among young people inclined toward the $\mathrm{LCC} / \mathrm{SKH}$, but also among a wider reading audience, becoming some sort of a brand. Youth journals were funded either from the funds of the Republic Self-management Interest Community for Culture (RSIC, Croatian: Republička samoupravna interesna zajednica kulture - RSIZ) and its local affiliates or through the ASYC/SSOH. ${ }^{7}$ The book The Yugoslav Youth Press by author Marko Zubak should be consulted for a detailed description of the phenomenon of Yugoslav youth press.

4 HR HDA 1220, Savez komunista Hrvatske. Centralni komitet (further: HR HDA 1220, SKH. CK), No. D-11334, “Analiza glasila mladih Istre 'IBOR”, 20 November 1979, 2, 3.

5 Istarski borac, accessed December 18, 2018, Metelgrad - Digitalizirani časopisi, http://library.foi.hr/m3/kds1.php?B $=1 \&$ sql $=S 02008 \&$ ser $=\&$ sqlid $=1 \&$ sqlnivo $=\& \mathrm{css}=\& \mathrm{H}=$ pula $\& U=05$.

6 Marko Zubak, The Yugoslav Youth Press: (1968-1980): student movements, youth subcultures and Communist alternative media (Zagreb: Srednja Europa; Hrvatski institut za povijest, 2018), 307.

7 See: HR HDA 1231, Republička konferencija Saveza socijalističke omladine Hrvatske (HR HDA 1231, RK SSOH) and HR HDA 1605, Republička samoupravna interesna zajednica kulture (HR HDA 1605 RSIZ). 
The youth press in Croatia went through sort of a crisis, primarily a financial one, but also a personnel crisis, in the 1970s. None of the youth journals were profitable, but they were financed from the republic or local budget because the political significance of their publication was greater than the financial one. Personnel problems are partly related to the inadequate number of highly educated young journalists, the "personnel void" created after the Croatian Spring in 1971 and the dismissal of a large number of journalists, as well as their inadequate ideological background. ${ }^{8}$ Omladinski tjednik, the only Croatian journal with a broader republic and federal media reach, stopped coming out in $1976 .{ }^{9}$ Several local youth journals - Laus, Val and Riječ mladih were coming out in Croatia at the time, and Pula's youth journal was launched again in 1976 under the new name IBOR. In the same year, Omladinski tjednik, a journal whose launch has long been invoked by youth leaders from RC of ASYC/RK SSOH and the more prominent media (Komunist), replaced Polet as the republic youth journal. ${ }^{10}$

The Information Committee of the Republic Conference of the Alliance of Socialist Youth of Croatia (RC ASYC/RK SSOH) held a meeting on May 29, 1980. The topic of the meeting was "current problems of the youth press" and the writings of Studentski list, Omladinska iskra and Polet were discussed. An analysis of the situation in the youth newspapers was prepared for the meeting, from which the expectations of the government and the relationship towards the youth press can be seen. ${ }^{11}$ Their opinion is that "a lot of effort needs to be made to ensure that the youth press is truly an integral element of socio-political activities and in the role of the Alliance of Socialist Youth". ${ }^{12}$ At the same time, the role and tasks of the youth press should be judged "precisely from the standpoint of putting them into the function of accomplishing the complex tasks of the Alliance of Socialist Youth of Croatia in social transformation and development of socialist self-management" ${ }^{13}$ Furthermore, the ASYC/SSOH is of the opinion that youth newspapers in the self-managing society should work together with the ASYC/ $\mathrm{SSOH}$, and that the youth press serves not only to provide information, but must also work actively in the youth organization and the society as a whole. The ASYC/SSOH thought that in the youth newspapers there are visible deviations going to two extremes: "The youth newspapers informs about the actions of the Alliance of Socialist Youth of Croatia in a dull, non-communicative and to youth unattractive newsletter style, and other, far more often is that youth newspapers 'forget' their founder, their social role, responsibility and tasks, and turn not to the ASYC/SSOH, as a socio-political organization of youth, but simply to young people, forgetting that as the ASYC/SSOH journal they should be, not only generationally, but necessarily ideologically committed, therefore in the function of interests and activities of youth that is socialist-oriented". ${ }^{14}$

\footnotetext{
Željko Krušelj, Igraonica za odrasle: Polet 1976.-1990. (Rijeka: Adamić, 2015$), 37$.

Ibid., 27.

10 Ibid., 30, 31.

11 HR HDA 1231, RK SSOH, box. 586, “Aktualni problemi omladinske štampe," May 27, 1980.

12 Ibid., 1.

13 Ibid., 2.

14 HR HDA1231, RK SSOH, box. 586, “Aktualni problemi omladinske štampe," May 27, 1980, 2.
} 
The aforementioned document about the state of the youth press in 1980 highlights that the overall information system is designed to activate and involve "working people" and youth in self-managing processes, in order to "objectively inform" the youth about the issues of "social life, work and creativity (...) and in the function of achieving the social tasks of the Alliance of Socialist Youth". It is stated that the youth press has a great educational function in "explaining the essence and contradictions in our development, which clearly makes it an active element of the ideological struggle against provincialism (philistinism), bureaucratism, technocracy, nationalism, dogmatism, and other anti-socialist and anti-self-managing tendencies". ${ }^{15}$ It is further stated that the youth press is largely focused on the "marginal problems of the society as a whole", that it often problematizes the "marginal social groups and phenomena" and thus poses a certain "danger in the conceptual sense, not because these phenomena are not worth writing about but because in regards to the real problems, questions, and dilemmas concerning further development of society, these marginal problems are being overemphasized", thus opening the possibility for the "manipulating antiself-managing and anti-socialistic forces to misuse it". ${ }^{16}$ It was also mentioned that the youth newspapers should distinguish themselves by "engaging and affirming in the revolution", but how such youth attitude was known to become "a dogma, turn into criticism, leftism, result in incidents, prohibitions, and wrongly highlighted social issues". ${ }^{17}$

The same document also states that the FR of Croatia had nine youth newspapers in the late 1970s: Polet, Studentski list, Val, Laus, Pet, Omladinska iskra, Lok, Ibor and Omladinac, all of them having in common unresolved material, personnel and spatial requirements. ${ }^{18}$

\section{Istarski Borac Literary Club and Journal Istarski borac / IBOR}

The Istarski borac Literary Club was the literary section of Pula's high school students, established in 1953. At its beginnings, the club was called the Literary Section of the Branko Semelić Gymnasium, and after its first issue in 1977 it was renamed the Istarski borac Literary Club. The year of the club's establishment was also the year when the journal of the same name was launched. Ljubica Ivezić was the mentor of the club during its entire existence, and also its founder. According to the editorial board of the first issue, the purpose of forming the club and launching the journal was to preserve the Croatian language and Croatian heritage in Istria and foster the development and affirmation of Istrian writers and intellectuals, cultural workers, journalists, scholars and politicians.

15 Ibid., 3.

16 Ibid., 4, 5.

17 Ibid., 3.

18 Ibid., 7. 
The activities of the Istarski borac Club are best known from the Istarski borac. The journal was published from 1953 to 1979, with two interruptions (1964 to 1969 and from 1974 to 1976 ) and it changed its name several times: 1953 to 1961 it was called Istarski borac, from 1961 to 1964, Glas mladih, from 1969 to 1974, Istarski borac, and from 1976 to 1979, IBOR.

In the twenty-six years of its existence, the literary club had produced numerous intellectuals and artists who left a great mark in the cultural history of Istria and Croatia and it achieved its basic objective: preserving the Croatian language. According to the Marija Petener-Lorenzin, author of the bibliography of Istarski borac/IBOR, this periodical "left a mark in the recent cultural history of Istria and journalistic production in this area," so that the compilation of its bibliography became a necessity. ${ }^{19}$

\section{"IBOR Case"}

There was a debate going on among the government bodies of ASYC/SSOH and RSIC/RSIZ about the cessation of its funding even before Istarski borac/IBOR became the "IBOR Case". The stated reasons for termination of funding were failure to fulfill the taken obligations, primarily half as many published issues as planned in the years 1978 and 1979, and not submitting annual work reports. After the "IBOR Case" became public, and after making a detailed analysis of the journal's writing (see the succeeding text), objections were directed toward the journal's wrong approach when writing about social issues and an "ideological orientation that is foreign to our self-managing socialist society" ${ }^{20}$

Dolores Petrinić thinks that Istarski borac was started "with the mission of spreading literacy and a positive attitude toward the Croatian language and literature". ${ }^{21}$ And since it published texts that "reflected the current cultural and social issues in a reasoned and engaging way" and how the IBOR had a tendency of growing into a journal "that would seriously and critically address not only literature but also culture and society in general." Petrinić believes that escaping political control led to the termination of the journal. ${ }^{22}$ The crucial moment was the publication of a translation of the English-language poem with paedophiliac/homosexual content, "Please Master," by Allen Ginsberg, published under the issue's theme "Total Institutions." The Istrian editions of the daily newspaper Večernji list and Glas Istre repeatedly wrote about the "IBOR Case," and the youth journals in Zagreb also became interested. After several months of Party and media debate, funding for the journal was cancelled, and as the result of a private lawsuit by journalist Armand Černjul, the editorial board was convicted for defamation on October 8, 1980.

19 Marija Petener-Lorenzin, Bibliografija časopisa "Istarski borac" - "Ibor": (1953.-1979.) (Pula: Istarski ogranak Društva hrvatskih književnika, 2006), 5.

20 HR HDA 1220 SKH. CK, No. D-11334, “Analiza glasila mladih Istre 'IBOR,” November 20, 1979, 2.

21 Dolores Petrinić, Hrvatska književnost $u$ istarskim časopisima druge polovice XX. st. (Rijeka: Društvo hrvatskih književnika, 2007), 9.

22 Ibid., 11. 
Boris Domagoj Biletić was a member of the last editorial board of $I B O R$, and one of the people conditionally sentenced to one month and fifteen days in prison for defamation of the journalist Armand Černjul. As Biletić testified, the formal reason for the verdict was "quasi-naive: translation of the poem 'Please Master' by Allen Ginsberg (who wrote a dedication to the last editorial board a few years later). But the real reasons were, in fact, that in some youthful texts (...) we had dared to question them (the Party!), and we were additionally interested in anti-psychiatry, in the almost poetically pure student year of 1968 in Europe and here, i.e. student protests, the Croatian Spring, Jim Morrison, anarchism ( ... Can you imagine, at that time, some young people in some place called Pula wrote, published, and were the leaders of the whole generation, and not under the umbrella of the so-called socialist youth?!"23

\section{IBOR's Last Issue and Poem “Please Master"}

The last issue of IBOR dealing with the topic of total institutions or comprehensive institutions, with special emphasis on psychiatric institutions, came out in September 1979. Using the deductive approach, starting with the profiling of totalitarian institutions, focusing on psychiatric institutions and their patients, the editorial draws conclusions, referring to eminent historical personalities from the fields of philosophy, historiography and culture, that an artist can only be a person who is either on the border of madness or has already passed that boundary. This is backed up by a series of texts and poems, the most provocative among them being "Please Master" by American poet Allen Ginsberg. The poem deals about a paedophiliac-homosexual relationship between a pupil and a teacher and is accompanied by a photo of a child named after the poem.

The poem aroused great controversy in Pula's Party and youth circles, and in republic, local and youth publications, and it was the formal reason for abolishing the journal's funding. Speaking of topics that were considered undesirable in conservative Pula, but also about the social circumstances in Yugoslavia that bothered the stateparty leadership, the IBOR editorial board's notable cultural-opposition activity was what ultimately led to the cessation of its funding.

\section{Governmental Attitude Toward "IBOR Case"}

The relation of socialist authorities toward the IBOR journal and the "IBOR Case" can be seen from the documentation of the Alliance of Socialist Youth of Croatia (ASYC/SSOH), the Central Committee of the League of Communists of Croatia

23 Matica hrvatska [Matrix Croatica], http://www.matica.hr/kolo/408/nacionalno-i-univerzalno-u-obzorima-zavicajnosti-23142/. 
(CC LCC/SKH CK) and the Republic Self- Management Interest Community for Culture (RSIC/RSIZ).

The work and funding of youth and other journals were followed by the RSIC/ RSIZ Commission for Journals and Newspapers in Culture. In its report from February 1979, it mentioned IBOR and journal Vrabac, clearly stating that: "Following the work of these journals through 1978, the Commission concluded that contributions do not exceed the level of quality of the first attempts and therefore do not meet the criteria. The source of funding should certainly be the municipal SIC/SIZ for culture."24 Two months later IBOR was again mentioned in the report of the same commission because it did not submit the report and was therefore denied payment of the remaining funds for 1978: "The Commission proposes that the journals which did not carry out the obligation of submitting the report even after the repeated warning be denied payment of the remaining funds. This refers to journals: Čakavska rič, Dubrovnik, Haiku, Ibor, Polet and Vidik."25

Certainly the most important document pertaining to the "IBOR Case" is the "Analysis of Istria's Youth Journal "IBOR". The document, signed under the name "Workgroup" and dated Pula, November 20, 1979, was created for the $37^{\text {th }}$ session of the Municipal Conference Committee of the LCC/SKH Pula held on November 27, 1979. The main topic of the meeting was the journal IBOR. It is a seven-page document that analyzes IBOR's work from 1973 to the latest issue 4-5 in 1979. The analysis focuses primarily on the editorial and associate staff of the journal, which, following the conclusions of the analysis is not up to the task, and does not give enough space to young authors instead forcing the affirmed authors. At the same time, IBOR was publishing primarily the works of the members of the Istarski Borac Literary Club, and very rarely the works of "young authors from the wider area of Istria." ${ }^{26} \mathrm{It}$ is seen from the document that the editorial board has been previously warned to give more space to the non-established authors. IBOR's unfulfilled obligations were also pointed out, as fewer issues than planned were published annually. For example, eight issues were planned for the year 1978 and only three (1,2-3 and 4-5) were realized. Another eight issues were planned for the next year (1979), five were officially published, while only two double issues (1-3, 4-5) were actually published. The topics that the journal dealt with were also problematic, they were not satisfactory because they "exclusively dealt with the issues from the area of the Pula commune". ${ }^{27}$

From the document we find out that the Istarski Borac Literary Club had 50 members (20 high school students, 15 university students and 15 employees) in the final year of its publishing (1979), and was conceptually oriented toward three areas

24 HR HDA 1605, RSIZ, box 4, 57. Session IO (26.3.1979.), "Prijedlog programa časopisa za 1979. godinu," February $1979,10$.

25 HR HDA 1605, RSIZ, box 4, 58. Session IO (13.4.1979.), "Prijedlog za isplatu preostalih sredstava iz 1978. godine," April 1979, 2.

26 HR HDA 1220, SKH. CK, No. D-11334, “Analiza glasila mladih Istre 'IBOR”, November 20, 1979, 1.

27 Ibid., 1. 
- culture, literary creativity and social issues. ${ }^{28}$ The journal was criticized for not writing enough about young people "about young man's role and place in our self-managing society, his problems and aspirations beyond the rock music and sports like problems of young people's employment, student self-management, deviations in young people's behavior". ${ }^{29}$ It was also pointed out that in most cases IBOR's writing was destructive, and the reason for this was that for some authors "this approach and a way of writing about our social reality reflects their ideological orientation which is foreign to our self-managing socialist society". ${ }^{30}$

The Executive Board of the SIC/SIZ discussed the IBOR at its session on October 6,1978 , with a special emphasis on the "socio-political orientation and literary value of the journal". It was then concluded: that the approved conception of the journal was not achieved; that the program orientation of the journal was to be taken over by the DC ASYC/OK SSOH Pula; that the journal should be made more "social" by applying the delegate principle, and that the funds are to be suspended until this condition are fulfilled. ${ }^{31}$ Soon the DC ASYC/OK SSOH Pula held another session which concluded that the financing of IBOR should be continued until a joint youth journal for whole Istria is launched and that one representative from the DC ASYC/ OK SSOH Pula and the SIC/SIZ for Culture Pula should enter the editorial board of $I B O R .{ }^{32}$ Aliče Davosyr as a representative of the SIC/SIZ and Ljubo Marčeta on behalf of the DC ASYC/OK SSOH entered the editorial board. As the plan for the first half of 1979 was not realized, the Republic SIC/SIZ suspended the financing of IBOR. ${ }^{33}$ The Istarski Borac Literary Club proposed that the journal should also be funded in 1980, but the Republic SIC/SIZ rejected it again. The SIC/SIZ thought that the IBOR "is not oriented toward socially acceptable movements and that it must contain socially acceptable content". The analysis concluded that financing of IBOR should be continued but at the local level. ${ }^{34}$ However, IBOR's funding was nevertheless suspended. It is not possible to determine from the archives why weren't the recommendations of the working group that made the analysis acted upon. The record of the session held on November 27, 1979, on which IBOR was discussed, does not exist. In the Croatian State Archives in Zagreb and in the State Archives in Pazin there is only a call to the session and the document "Analysis of Istria's Youth Journal 'IBOR" but not the record of the session itself.

In the entire document, only one sentence mentions the last issue of $I B O R$ (4-5/1979) because of which the entire "IBOR Case" was initiated. The sentence reads: "Meanwhile, the latest double issue 4-5/79 came out containing a lot of inappropriate articles especially for the age group journal is intended for i.e. young

28 Ibid.

29 Ibid., 2.

30 HR HDA 1220, SKH. CK, D-11334, “Analiza glasila mladih Istre ‘IBOR,” November 20, 1979, 2.

31 Ibid., 4.

32 Ibid.

33 Ibid., 5.

34 Ibid., 6, 7. 
people". ${ }^{35}$ Such disregard for the content of the last issue gives the impression that the poem "Please Master" may not be a reason IBOR's funding got canceled. Even more so because the emphasis of the key analysis was on non-fulfilling the obligations, the absence of young non-established authors and the ideological turn of the editorial board which is reflected in improper writing about the Yugoslav self-managing socialist society.

\section{Media and "IBOR Case"}

The "IBOR Case" had, in addition to great interest of the government, also caused great interest of regional media and youth journals. As mentioned earlier - it was mostly written about in Glas Istre and the Istrian edition of Večernji list, as well as the republican youth journals Polet, Pitanja and Studentski List. The republic newspaper Vjesnik - Sedam dana devoted a series of seven articles to the "IBOR Case" in which the case was analyzed in detail. The articles published in Glas Istre are of a more informative character and primarily present the conclusions of the DC LCC/OK SKH Pula and the DC ASYC/OK SSOH. The articles in the Istrian edition of Vecernji list are signed by Armando Černjul, and are partly characterized by the informative approach and partly by the author's engagement and his unreserved condemnation of the IBOR's editorial board for the poem "Please Master". Youth journals make room for discussion by publishing articles signed by IBOR's last editorial board and articles by Armand Černjul, as well as texts by authors not directly related to the "IBOR Case".

In one of Armando Černjul's first articles about the "IBOR Case" published in the Istrian edition of Večernji list the author wonders whether people in IBOR think that Istria's youth "for whom the journal is intended is interested in homosexual ranting?" 36 The IBOR's editorial staff answered in the same newspaper to the allegations in relation to publishing the poem "Please Master". They stated that the "unfortunate Ginsberg is a cause of much casual gossip and labeling of IBOR's editorial staff from the "filters" of social morality such as A. Č. The civil terms "swear words" and "vulgarities" simply fade away as archaism compared to those as stylemes without which one period of literary creativity is missing in the world and here. It seems that the individuals must be repeatedly reminded of the well-worn statement that the appreciation of the artistic level of a particular literary work is mainly in the domain of poetics, literary criticism and aesthetics, and by no means a tool for political discredit by drawing out of the context of a whole." ${ }^{37}$ Cernjul wrote his answer already in the next issue: "As for the poem 'Please Master' by A. Ginsberg, which is presented by the members of IBOR's editorial staff, thinking perhaps that Pula and other places in Istria have problems with homosexuality in education, then they should have disclosed their opinion on their

35 Ibid., 6.

36 Armando Černjul, 'Kome služi “Ibor’?, Večernji list (Istrian), October 3, 1979, 6.

37 IBOR Redaction, “Fusnote za A. Černjula”, Večernji list (Istrian), November 1, 1979, 6. 
own, and not seek 'help' from the American poet and professor. How to otherwise explain to the reader of $I B O R$, and now 'Večernji List', that the people in IBOR are mistaken. They would have to look at the last page of the IBOR, on which the photo was published showing at best three year old lying prone on the road, surrounded by adults and signed 'Please Master.' If people in IBOR don't know what they have done with it, then they are not up to the job they are doing, because the photograph in the context of the poem 'Please Master' by which it is named, undoubtedly puts the innocent child into the center of homosexual lust. Everyone must be disgusted by it!"38

A cosmopolitan, writer and scholar Predrag Matvejević also referred to "IBOR Case" in an interview for Polet. When asked by journalist Vladimir Cvitan: "When it comes to 'Ibor' and dismissing its editorial staff, it is generally taken as known that by publishing Ginsberg's poem 'Please Master' a mistake has been made?” Matvejević answered: "I think publishing one somewhat challenging poem of one good poet (a poem that speaks of homosexuality) is more mischief than a mistake. Do not forget that one issue of 'Domet' dedicated to erotics was nearly prohibited in Rijeka." ${ }^{39}$ Regarding Matvejević's response in which he stated that the poem is of homosexual character, the question arises as to whether Matvejević was really familiar with the words of the poem and the fact that the editorial team accompanied the poem with a photograph which they named after the poem's title and which shows the boy of preschool age. Given the words of the poem and the photograph which is explicitly related to the poem, it is more than obvious that it is a poem of pedophilic character, while the homosexual part of the poem's character is probably less important because homosexualism was decriminalized in socialist Yugoslavia in 1977. Armando Černjul referred to an interview with Matvejević in the earlier mentioned article "Enough with crude disinformation". Černjul stated that Matvejević and journalist Cvitan give inaccurate information about the "IBOR Case" and how they are wrongly informed. Černjul thinks that one of the reasons for Matvejevićs misinformation is the visit of IBOR's editorial board to Professor Matvejević. ${ }^{40}$

Slavko Kalčić and Aldo Monfardin, two members of the last editorial board of Istarski Borac/IBOR, published the article "IBOR Case" in the newspaper Pitanja in 1980. In the article they respond to the attacks in other newspapers, especially Armando Černjul's texts and the accusations from the DC ASYC/OK SSOH. As a defense to Černjul's accusations of vulgarism, and in relation to the poem "Please Master", they state that Černjul takes the photograph and the poem "out of the context of the issue's theme (Total institutions), pretending not to understand or indeed not understanding the term literary, simultaneously vulgarizing it and attacking IBOR with low blows using the arsenal of Christian moralism" ${ }^{41}$ Answering the accusations from the DC ASYC/OK SSOH (which were published in Glas Istre, issue from December 3, 1979), that many articles published in IBOR were "not suitable, especially for the age of those

38 Armando Černjul, “Bez kormila," Večernji list (Istrian), November 2, 1979, 6.

39 Vladimir Cvitan, “Intervju: Predrag Matvejević. Dosta gruba smjenjivanja," Polet (Zagreb), January 23, 1980, 9, 10.

40 Armando Černjul, “Dosta grube dezinformacije,” Polet (Zagreb), February 6, 1980, 2.

41 Slavko Kalčić and Aldo Monfardin, “Slučaj ‘Ibor,” Pitanja (Zagreb), No. 3 (1980), 71-77. 
the journal was intended for", the editorial staff relativised these claims and said that such a label could "usually be found on Danish-Swedish film co-productions!". They focused on the second part of the accusations, which state that part of the inscriptions is unacceptable "as a way of presenting our social reality". The part about presenting "our social reality" is deemed crucial by IBOR's editorial board, and they confirm it with Rakočevićs article published in the Istrian edition of Večernji list from December 4, 1979. In the article Rakočević accused them of publishing the texts with "views that are foreign to our self-managing and socialist society, impose a destructive approach to the treatment of social topics and problems, and instead of being a forum for young people, IBOR increasingly becomes a ground for the nebulous wisdom of individuals." Further in the text, as a sort of conclusion, the authors pointed out that one "poem instead of giving aesthetic and cognitive pleasure resulted in extraordinary sessions, work groups ( ... It is wrong, however, to think that the song missed its purpose. On the contrary, it fulfilled it entirely by bringing to light the hereditary illness of a closed community. Instead of a word no one listens to under the dome of deaf indifference, the poem has become the catalyst for the events." ${ }^{43}$ As a key part of their defense in this article, the authors emphasized the "Marxism" of their actions and the fact that "the coupling of sexual and political inhibition" is joined against them: "To speak out about this means to touch into the sacrosanctness of the 'guardians' of such activity. We come to an important problem in the whole case: isn't the 'freedom of speech' lower in provincial conditions where the local totems rule, and where political and sexual are not yet free from taboos? It is not by chance that in one particular case sexual and political merge by cause and effect relationship as the initiators and the mechanisms of silencing. Historical analysis of the written/spoken word in relation to these two areas would show that they were, in fact, its limiters in societies without freedom/democracy. Boasting with progressive consciousness is not uncommon in these times, but progressive consciousness is not in Marxist phrases, but in Marxist deeds. We think that IBOR's work is Marxist in its critical, open and argumentative writing. In the surroundings where ideas are often critiques for the local autocracy, every critique is known to be met with intolerance. That is why people in IBOR were marked as critics and were objected for not highlighting the positive examples from our reality".44

\section{Verdict Against the IBOR Editorial Board}

The "IBOR Case" was mostly covered by journalist Armando Černjul, writing for the Istrian edition of the daily newspaper Večernji list and Polet. It was his article in Polet ("Enough with crude disinformation," February 6, 1980) that prompted IBOR's editorial board to react with another article in Polet ("Photogenic falsifier," February

42 Ibid., 73.

43 Ibid.

44 Slavko Kalčić and Aldo Monfardin, “Slučaj 'Ibor," Pitanja (Zagreb), No. 3 (1980): 71-77. 
19, 1980), in which they stated that Černjul has a "Zhdanovist temper", that he is a "press-agent in the service of power", and a philistine. ${ }^{45}$ Cernjul filed a private lawsuit for slander and defamation against the IBOR's editorial staff. The court dismissed the part of the suit pertaining to slander, but ruled against members of the IBOR's editorial board (Nevenko Petrić, Boris Biletić, Slavko Kalčić, Miomir Kalčić, Josip Ivančić and Ivan Pletikos) for defamation and assigned each "a month and a half suspended sentence and one year of probation." At the request of the plaintiff (Černjul), and pursuant to the court's decision, the verdict was published in Polet. ${ }^{46}$

The trial was held at the County Court in Pula and the second-instance verdict was passed on October 8, 1980. The Council that issued the second-instance verdict was constituted of the Council's president Zvonimir Pajdaš and members Ante Črnja and Milojka Vučković, while Željko Franješević defended IBOR’s editorial board. As mentioned earlier, the second-instance court rejected part of allegations referring to slander and the editorial board of Istarski borac/IBOR was only convicted for defamation. In addition to paying the cost of publishing the verdict in the Polet newspaper, the members of the editorial board were obliged to pay the costs of the criminal proceedings and each paid the sum of 200 dinars. The verdict contains the court's belief that the offenders "will not repeat such and similar criminal offenses in the future". ${ }^{47}$

\section{Conclusion}

Following all that was said, it is evident that the "IBOR Case" is very complex and it is not easy answering the question of whether it classifies as a culture of dissent or not. The IBOR was discussed in the party circles even before it became a public case, i.e. prior to publishing the issue 4-5/79 and the poem "Please Master". At the time $I B O R$ was criticized for not giving enough space to young authors, not submitting reports, publishing only a half of planned issues for 1978 and 1979, and dealing primarily with the issues of the Pula commune. After the outbreak of the "IBOR Case", Party's analysis of the IBOR put an emphasis on the non-fulfillment of obligations, the absence of young non-established authors and the ideological turn of the editorial board, which is reflected in improper writing about the Yugoslav self-managing socialist society. The analysis ignored the poem "Please Master" only briefly stating that the last issue of $I B O R$ was full of vulgarity. This disregard for content of the last issue gives the impression that the poem "Please Master" was perhaps not the reason why the financing of $I B O R$ was cancelled and that the reason lies in the "destructive" writing of some authors - "this approach and a way of writing about our social reality reflects their ideological orientation which is foreign to our self-managing socialist society".

45 Polet(Zagreb), February 19, 1980, 2.

46 Polet (Zagreb), November 5, 1980, 2.

47 Polet (Zagreb), November 5, 1980, 2. 
On the other hand, the editorial board thought that their writing is critical, but not (culture of dissent) towards Marxism: "We think that IBOR's work is Marxist in its critical, open and argumentative writing" - but towards negative phenomena in society. Has the IBOR's editorial board really thought that their activity was Marxist or was it a defense against an attack that would reduce the damage done to IBOR and to them as individuals - this remains an open question and is subject to further interpretation. The IBOR's last editorial board can hardly be denied the courage to write about topics which were taboo and caused discontent in Pula's conservative surroundings. However, the editorial board was probably aware that the same topics would bring about discontent from the Party and that their actions put them at the limits of tolerance. With this kind of work, the editorial board of IBOR showed courage and resisted, if not to Marxism as they themselves say, then to the community in which they lived and worked.

\section{Sources and References}

\section{Archival Sources:}

- HR HDA, Hrvatski državni arhiv, Zagreb:

- HR HDA 1220, Savez komunista Hrvatske. Centralni komitet.

- HR HDA 605, Republička samoupravna interesna zajednica kulture.

- HR HDA 1231, Republička konferencija Saveza socijalističke omladine Hrvatske.

\section{Literature:}

- Krušelj, Željko. Igraonica za odrasle: Polet 1976.-1990. Rijeka: Adamić, 2015.

- Peternel-Lorenzin, Marija. Bibliografija časopisa "Istarski borac" - "Ibor": (1953.-1979.). Pula: Istarski ogranak Društva hrvatskih književnika, 2006.

- Petrinić, Dolores. Hrvatska književnost u istarskim časopisima druge polovice XX. st. Rijeka: Društvo hrvatskih književnika, 2007.

- Zubak, Marko. The Yugoslav Youth Press: (1968-1980): student movements, youth subcultures and Communist alternative media. Zagreb: Srednja Europa; Hrvatski institut za povijest, 2018.

\section{Newspaper Sources:}

- Crnobori, Albino. "Što je za moju generaciju značio literarni klub 'Istarski borac". Istarski mozaik, No. 5-6 (1968): 412-15.

- Cvitan, Vladimir. "Intervju: Predrag Matvejević. Dosta gruba smjenjivanja." Polet (Zagreb), January 23, 1980, 9, 10.

- Černjul, Armando. “Dosta grube dezinformacije." Polet (Zagreb), February 6, 1980, 2.

- Černjul, Armando. “Kome služi 'Ibor'?” Večernji list (Istrian), October 3, 1979, 6.

- Glas Istre, 1979. 
- IBOR Redaction. "Fusnote za A. Černjula." Večernji list (Istrian), November 1, 1979, 6.

- Istarski borac, 1953-1979.

- Ivezić, Ljubica. "I jedna važna obljetnica između na koju ne treba zaboraviti," Dometi (Rijeka) No. 5-6 (1992): 95-100.

- Pitanja, 1980.

- Polet, 1980.

- Večernji list (Istrian), 1979.

\section{Online Sources:}

- Istarski borac. Accessed December 18, 2018, Metelgrad - Digitalizirani časopisi. http://library.foi. $\mathrm{hr} / \mathrm{m} 3 / \mathrm{kds} 1 . \mathrm{php} ? \mathrm{~B}=1 \& \mathrm{sqlx}=\mathrm{S} 02008 \&$ ser $=\& \mathrm{sqlid}=1 \& \mathrm{sqlnivo}=\& \mathrm{css}=\& \mathrm{H}=$ pula\&U$=05$.

- Matica hrvatska [Matrix Croatica]. http://www.matica.hr/kolo/408/nacionalno-i-univerzalno-u-obzorima-zavicajnosti-23142/.

\section{Lidija Bencetić}

\section{JOURNAL ISTARSKI BORAC/IBOR IN THE CONTEXT OF THE CULTURE OF DISSENT}

\section{SUMMARY}

Following all that was said, it is evident that the "IBOR Case" is very complex and it is not easy answering the question of whether it classifies as a culture of dissent or not. The IBOR was discussed in the party circles even before it became a public case, i.e. prior to publishing the issue 4-5/79 and the poem "Please Master". At the time $I B O R$ was criticized for not giving enough space to young authors, not submitting reports, publishing only a half of planned issues for 1978 and 1979, and dealing primarily with the issues of the Pula commune. After the outbreak of the "IBOR Case", Party's analysis of the IBOR put an emphasis on the non-fulfillment of obligations, the absence of young non-established authors and the ideological turn of the editorial board, which is reflected in improper writing about the Yugoslav self-managing socialist society. The analysis ignored the poem "Please Master" only briefly stating that the last issue of $I B O R$ was full of vulgarity. This disregard for content of the last issue gives the impression that the poem "Please Master" was perhaps not the reason why the financing of $I B O R$ was cancelled and that the reason lies in the "destructive" writing of some authors - "this approach and a way of writing about our social reality reflects their ideological orientation which is foreign to our self-managing socialist society".

On the other hand, the editorial board thought that their writing is critical, but not (culture of dissent) towards Marxism: "We think that IBOR's work is Marxist in its critical, open and argumentative writing" - but towards negative phenomena in 
society. Has the IBOR's editorial board really thought that their activity was Marxist or was it a defense against an attack that would reduce the damage done to IBOR and to them as individuals - this remains an open question and is subject to further interpretation. The IBOR's last editorial board can hardly be denied the courage to write about topics which were taboo and caused discontent in Pula's conservative surroundings. However, the editorial board was probably aware that the same topics would bring about discontent from the Party and that their actions put them at the limits of tolerance. With this kind of work, the editorial board of IBOR showed courage and resisted, if not to Marxism as they themselves say, then to the community in which they lived and worked.

\section{Lidija Bencetić}

\section{ČASOPIS ISTARSKI BORAC/IBOR V KONTEKSTU KULTURE DISIDENTSTVA}

\section{POVZETEK}

Prvi hrvaški mladinski časopis Istarski borac/IBOR je z dvema krajšima vmesnima premoroma izhajal med leti 1953 in 1979 v Pulju. Časopis je izdajal Književni klub Istarski borac, in sicer $\mathrm{z}$ namenom ohranjanja hrvaškega jezika $\mathrm{v}$ Istri kot temeljnim vodilom. V sedemdesetih letih 20. stoletja je časopis prevzel značaj kritičnega medija in postopoma uvajal vse več kulturnih, lokalnih in družbenih tem, katerih ton pa socialistična oblast ni dobro sprejela. Jeseni leta 1979 je izbruhnil »primer IBOR $\ll$. Časopisu so istega leta ukinili financiranje, zaradi česar je prenehal izhajati. Povod za ukinitev časopisa je bila sicer pesem z naslovom Please, master (hrv.: Molim te, učitelju) Allena Ginsberga, toda partijski dokumenti razkrivajo, da je bil razlog političen. Pričujoča razprava poskuša odgovoriti na vprašanje, ali je delovanje zadnjega uredništva časopisa Istarski borac/IBOR mogoče obravnavati kot kulturo disidentstva.

$\gg$ Primer $I B O R_{\ll}$ je dokaj zapleten, zato odgovor na vprašanje, ali je pri njem šlo za kulturo disidentstva ali ne, ni preprost. O časopisu IBOR so v partijskih krogih razpravljali še pred javnim odprtjem primera oziroma pred izdajo številke 4-5/79 in pesmi Please, master. Takrat se je govorilo, da časopis ne daje dovolj prostora mladim avtorjem, da ne oddaja poročil o delu, da je leta 1978 in 1979 objavil pol manj številk, kot je bilo predvideno, in da se ukvarja predvsem s problematiko puljske komune. Po izbruhu »primera $I B O R \ll$ je v partijski analizi opaziti poudarek na neizpolnjevanju obveznosti, izpustu mladih, še neuveljavljenih avtorjev in idejnem odklonu uredništva, kar naj bi se odražalo v nepravilnem pisanju o jugoslovanski samoupravni socialistični družbi. V analizi je sicer prezrta pesem Please, master, pri čemer je zgolj na kratko omenjeno, da je zadnja številka časopisa IBOR polna prostaštva. Tovrstno ignoriranje 
vsebine zadnje številke zbuja vtis, da pesem Please, master ni bila razlog za umik financiranja časopisa IBOR. Nakazuje namreč, da je razlog vendarle »destruktivno « pisanje nekaterih avtorjev, saj da »tak pristop in način pisanja o naši družbeni stvarnosti odražata idejno opredelitev, ki ni v skladu z našo samoupravno socialistično družbo «.

Po drugi strani pa je samo uredništvo bilo mnenja, da je njihovo pisanje sicer kritično, vendar ni kritično (culture of dissent) do marksizma: »Menimo, da je delovanje časopisa IBOR marksistično po svojem kritično usmerjenem, odprtem in argumentiranem pisanju «, toda kritično naravnano do negativnosti v družbi. Vprašanje o tem, ali je uredništvo časopisa IBOR v resnici menilo, da je njihovo delovanje marksistično, ali je šlo zgolj za obrambo pred napadom, $s$ katero so hoteli omiliti škodo, ki so jo utrpeli $I B O R$ in člani uredništva kot posamezniki, je ostalo odprto in predmet naknadnih interpretacij. Nikakor pa zadnjemu uredništvu časopisa IBOR ne gre oporekati poguma, $\mathrm{s}$ katerim so se lotili pisanja o tabu temah, ki so izzvale nezadovoljstvo v konservativnem puljskem okolju. Kljub temu so se njegovi člani najbrž zavedali, da bodo ravno te teme povzročile negodovanje tudi v Partiji in da se s svojim delovanjem pomikajo proti sami meji tolerance. $S$ takim delovanjem je uredništvo revije $I B O R$ pokazalo pogum in se uprlo, če že ne marksizmu, kot so dejali sami, pa gotovo vsaj skupnosti, $\mathrm{v}$ kateri so delovali in živeli. 